\title{
The Real Lies: The Simulacrum in Catherine Fisher's The Oracle
}

\author{
Anna Free
}

Fiction written for children and young adults has absorbed postmodern culture in many ways, overtly in some picture books, and more covertly in other young adult fiction. One aspect of postmodernism is concerned with what is real, what is more real, and what constitutes the simulacrum. The simulacrum concerns the surface of things, the ability to copy, and (in a postmodern sense) the ability of the original to disappear. Examples of this in young adult cultures exist in abundance, and yet even though the text chosen for this paper is set in an imagined world it illuminates the confrontation between the real and the unreal for the postmodern young adult subject. Drawing on Jean Baudrillard (1994) and Jacques Derrida (1974), I investigate the simulacra and the surfaces that represent belief and social order in Catherine Fisher's The Oracle (2003), where Mirany provides a sceptical subject position for young adult readers. I argue that peeling back the layers of representation, looking under the surface, reveals only more surface and more representation, making 'surface' (or 'outer face') a tautology. The 'realness' of the surface is deceptive. What can be seen with the eye, or touched with the hand is no longer trustworthy.

The use of a fantasy text to study the real is congruent with the selection of theoretical perspectives I have chosen for this paper. Baudrillard's concept of the simulacrum moves through various stages, from the masking of reality to the masking of a lack of reality. The first stage is a reflection of a basic reality, the second a mask or perversion of that reality. The third stage masks the absence of a basic reality, and is illustrated with the often used example of Disneyland, which 'is presented as imaginary in order to make us believe that the rest [of America] is real' (1983, p.12). The fourth stage is the 'triumph of the virtual over the real'(1995, p.50), where the simulation is so convincing that we no longer search for any truth behind it, or perhaps we do not believe that there is a truth to be found.

The surface is all that is left as the sign has no signified that can be accessed, pin pointed or held down: it becomes a self-referential cycle. Or as Derrida states: in the 'contrary movement of language the... signifier of the signifier' is caught in the 'circulation of signs,' and subsequently 'conceals and erases itself in its own production' (1974, p.7); it is the 'play of signifying references that constitute language' (Derrida 1974, p.7), or the play of signs. The fantasy text provides unique opportunities to look at the 'Disneyland' of fiction in its subtle exploration of the real. I will use a young adult text to map phases two, three and four of the simulacrum, and where Baudrillard falls short, there is Derrida to lean on.

My focus text, The Oracle, is set in an ancient Egyptian society that is ravaged by drought. It follows the journey of Mirany as she moves from searching for something real behind an image, to adjusting her concept of what is real. Her battle with subjective agency is a battle with these concepts, and she engages with a process of discovering where her own boundaries lie. She is a young priestess-like (secret) non-believer, as she helps the god-on-the-earth (The Archon, similar to a religious figure head / pharaoh) attain his rightful place despite corruption in the temple. Mirany begins as a non-believer in the god, in a society that is based around its collective belief, and she serves the god as one of 'the Nine', priestess-like girls and women who devote their lives to serving the god. Each lives a privileged life enjoying all the luxury the poor citizens can give. In the text the god takes many forms though he is one consciousness, at times he is a voice in Mirany's head, or he is embodied in a boy Alexos (the Archon), and he even appears as a scorpion. At the beginning of the text Mirany has just been given the role of 'The Bearer' to carry the bronze bowl holding the god (as scorpion).

When the god is an actual presence, as in this text, it does not appear to provide any additional assurance that there is a more stable underpinning to the beliefs of the society or characters. 'Reality' as a concept is subtly mistrusted in the text, with both Mirany's ambivalence about the reality of her existence as a priestess, and belief in the god. This instability is further supported in the text by the proliferation of corruption and bribery that casts doubt on the façade of social order. In what would seem on the surface to be an ordered and religiously orientated society, it nevertheless takes money to do anything (even to become a priestess), and the Nine are always aware of this monetary aspect. They are furious that Mirany is promoted to the Bearer, as they all knew her father had 'schemed and plotted and bribed to get her in' (p.24), and she was promoted above her more aristocratic peer who should have been next in 
line. Mirany's friend and scribe, Seth, also has a darker side, as he sells maps of the tombs in exchange for water (albeit for his sick sister). Seth conspires to rob the tombs, which brings the underworld of the City to light. Their dealings show that the respect for the dead (in the City of the Dead) is not universal, and that most tombs have been robbed at some point. This shows a society in denial, outwardly only recognising a perversion of the actual goings on, and the ceremony that visitors to the city see is no more than a mask - the second stage of the simulacra.

To compound this unreliability, Alexos (the new Archon, and who is possessed by the god) tells Mirany to beware of those trying to harm her:

\section{'They've tried once to hurt you.' \\ 'The god promised me. He said he wouldn't let me be hurt.' \\ Alexos dropped a pebble in the circle's heart. 'Yes. But what if the god tells lies?' \\ (p.237).}

Mirany is forced to trust in her own agency, her own decision to act in her world, and not rely on guidance from the god or others. Further to this, the mere concept that a god can lie brings the thrust of the text, the solid foundation of the society's religion, under suspicion. As the Oracle is held to be the voice of wisdom, and the voice of the god, what happens if the god tells lies? Alexos is only a ten year old boy, albeit with a god within him, and he seems to be feeling the weight of the burden he has placed on Mirany to help him. The possibility that the god tells lies also brings the focaliser-god further under suspicion as unreliable or fallible; a not-very omniscient narrator.

The corruption has spread to all levels of the society, and the falseness of one of the nine called the Speaker seems to be the worst betrayal of all as she is supposed to speak the words of the god heard at the Oracle: Mirany comments, 'Hermia was the traitor. Hermia had betrayed the Oracle. But then if there was no god anyway...' (p.80). Whether the god is lying or not is only important if someone is listening to the words at all. If the Speaker is deaf to the god, then there is a double betrayal, both the god's potential lies and the Speaker's lies. The realness of
Mirany's world is constantly under threat, things are not what they seem on the surface, and the simulacrum has taken hold. The deception goes deeper than the second stage of the simulacrum, Mirany now sees the absence of a basic reality, or the third stage.

Now I would like to apply a different point of view of the third and fourth stage, the pure simulacrum, the truth that masks the fact that there is none. The city of the Dead has its own grim Disneyland, where the character Kreon lives in a world under the pyramids full of papyrus and death records. He is the brother and shadow of the god, and never ventures out into the sunlight. Mirany and her companions first see his secret chamber in the tunnels during their attempt to hide the Archon. They are faced with a world that Kreon has made out of scraps of papyrus moulded into the riches of the tombs. On first appearance it is 'furnished like a palace... couches and beds and chairs and tables, gilt-edged, painted, wonderful' (p.269). But on closer inspection all the items are made out of papier-mâché, with 'the letters of the original papyrus showing through the paint, a ghostly genealogy' (p.270). The existence of this place, and the position of its creator, offers many avenues for investigating the play of signs.

The items are fakes, and moreover, they are constructed from words and lost text into what can be argued is more real than the real. The items that Kreon has copied are the riches of the tombs, placed with the dead Archons in the same manner as pharaoh's burials. Yet each piece of furniture or decoration is caught in the signification system, where it is more than merely a vase (for example), but is also signifying the importance placed on the after life, the value of the Archon, and the affluence of the society. This vase becomes the signified of Kreon's paper vase (the signifier), adding its own layer of meaning on top of both the vase's significance and the layers of papyrus: Derrida states that 'the signified always already functions as a signifier' (Derrida 1974, p.7). The papyrus and ink (the words on the page) become metonymic of this copying process. The copied vase connotes both the meanings of the vase in the tomb and the societal construction of things through language. Further to this, the use of scrap papyrus operates as a palimpsest, yet also shows how regardless of all the opulence of the original vase, it is in 
fact now left in the tombs as a remainder and an end point for signification, whereas the copy is still a functioning part of the signification chain in the world accessible by people. In this sense the copies can better represent the existence of the thing than the original vase. Further to this, according to the fourth stage of the simulacrum, the original vase is now a signifier and no longer an independently 'real' object at all.

Kreon calls his sculptures 'All copies. Shadows of the real' (p.271), just as he sees himself as a shadow of the god. However, he follows this later saying to Alexos the god: 'I have a kingdom too, where everything is a copy of your own. Or is it the other way round?' (p.337); this disturbs the privileged binary of original/copy (where the original is privileged). He may be suggesting that the world above the tombs is reliant upon and constructed through the existence and ceremony surrounding the tombs and burials, and that the tombs are a condensed microcosm of the society above. There are slaves, musicians, rich and poor, alongside the artefacts, food and water. The world below is also the world of words in this society, and where everything is written and recorded (by scribes such as Seth). Kreon's statement could imply that the records and language are not copies of the life above but constructing that life through language. Adding to this, he may also infer with his paper imitations of the tombs that the religion held so dear is merely held up by paper and money, and the outward beauty (or surface) is all that is worth relishing.

This concept is re-enforced during the burial ritual for the old Archon, which the novel is partly constructed around. There are nine ceremonial procedures, taking nine days, conducted by the nine priestesses (of which Mirany is one). By the end of this time, and after being bound in cloth, placed in numerous coffins and sarcophagi, Mirany comments, 'his old existence so far down under the layers it was lost' (p.121). The person that the Archon was becomes the representations of him (the engraved body on the lid of the sarcophagus, the statue in guarding the city, and the tomb itself) and the surface becomes more real than what lay beneath. Yet when taking the final stage of the simulacra into account, he did not exist as an original and the copy is all that is real: could the Archon be anything but his icons? He was not allowed to talk to anyone apart from the slaves for orders, he always wore a large golden mask in public, and could not venture out of his chambers without the mask and guard on official ceremonial business. He is also and perhaps most importantly, possessed by the god. The god now lives in a new body (Alexos's) and so the death of the Archon is under question as his divinity survives. The Archon's original identity is never known, yet must have at one point existed (as all the new Archons only appear at 10 years of age). All that is seen and remains are the icons and representations of the Archon, and the original is lost, if there ever was one, hence becoming the pure simulacrum. The icon of the mask becomes a reminder of the lack of substance, the pure surface of the society.

The deconstruction of images could be endless, and the prevalence of the simulacrum in societies (both fictional and actual) maintains that infinite process of signification. Kreon's palace manifests the inscribing of its infinite signification into the landscape of the text. Under the papyrus is more papyrus, covered with words that are caught in the signification process themselves. It appears that little in the reference world of this text is real, or reliable, and exists in a constant state of re-presentation in the play of signs. The god also proves unreliable, and lies are in abundance. Mirany's trust in her own agency saves her world from the potentially destructive forces of the simulacra. Despite the unreliable world around her, the decision to act (or not act) provides her with a power that she cannot borrow from any authority, or religious figure, and is the substance that overcomes the simulacra surrounding her. 


\section{REFERENCES}

Baudrillard, J. (1983) Simulations, New York, Semiotext(e).

Baudrillard, J. (1994) Simulacra and Simulation, Michigan, The University of Michigan Press.

Baudrillard, J. (1995) The Gulf War Did Not Take Place, Sydney, Power.

Derrida, J. (1974) Of Grammatology, Baltimore, John Hopkins University Press.

Fisher, C. (2003) The Oracle, London, Hodder Children's Books.

\section{BIOGRAPHICAL NOTE}

Anna Free is currently researching a PhD at QUT's Education Faculty. The title of her thesis is 'Representations of Post-Apocalypse in Young Adult Fiction' and it will be submitted in 2008.

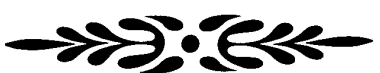

